\title{
Exploring Proactive Niche Market Strategies in the Steel Industry: Activities and Implications
}

\author{
Mikael Ottosson and Daniel Kindström \\ Journal Article
}

\section{Tweet}

N.B.: When citing this work, cite the original article.

Original Publication:

Mikael Ottosson and Daniel Kindström, Exploring Proactive Niche Market Strategies in the Steel Industry: Activities and Implications, Industrial Marketing Management, 2016. 55(2016), pp.119-130.

http://dx.doi.org/10.1016/j.indmarman.2015.08.003

Copyright: Elsevier

http://www.elsevier.com/

Postprint available at: Linköping University Electronic Press

http://urn.kb.se/resolve?urn=urn:nbn:se:liu:diva-128102

(c)

I.U UNNGDESGS 


\section{Exploring Proactive Niche Market Strategies in the Steel Industry: Activities and Implications}

Mikael Ottosson, Ph.D. (corresponding author)

Linköping University

Department of Management and Engineering

SE-581 83 Linköping

Sweden

+4613282260

mikael.ottosson@liu.se

Daniel Kindström, Ph.D.

Linköping University

Department of Management and Engineering

SE-581 83 Linköping

Sweden

+4613282496

daniel.kindstrom@liu.se

First time submitted: August 29, 2014.

Revision 1 resubmitted: February 27, 2015.

Revision 2 resubmitted: June 26, 2015. 


\section{Exploring Proactive Niche Market Strategies in the Steel Industry: Activities and Implications}

\section{Bio Page}

Mikael Ottosson, Ph.D., is Associate Professor of Marketing at Linköping University in Sweden. In his research, Mikael focuses on business development in mature industrial companies. He has published articles in journals such as Journal of Cleaner Production and Technology Analysis \& Strategic Management.

Daniel Kindström, Ph.D., is Associate Professor of Industrial Marketing at Linköping University in Sweden. He is currently conducting research on service infusion, proactive market strategies, and dynamic business models. His research appears in journals such as Industrial Marketing Management, Journal of Business Research, Journal of Service Management, and Journal of Business \& Industrial Marketing as well as in several books and book chapters. 


\section{Exploring Proactive Niche Market Strategies in the Steel Industry: Activities and Implications}

\section{Research Highlights}

- Niche marketing is often used as a defensive strategy.

- Niche marketing may, however, also be used as a proactive strategy.

- Proactive niche market strategies are examined in three global Swedish steel firms.

- We propose that a proactive niche market strategy employs five key activities. 


\title{
Exploring Proactive Niche Market Strategies in the Steel Industry: Activities and Implications
}

\begin{abstract}
The literature has often proposed a niche market strategy as the means by which producers of commodity-based products (e.g. steel, pulp and paper, and petrochemicals) can counter increasing competition, particularly from low-cost, low-price competitors. That strategy has primarily been viewed as defensive, i.e. the weaker producer builds protective barriers around its product to fend off competition. This paper proposes, on the contrary, that niche marketing can also be used as a proactive, or even aggressive, strategy to enable a firm to outperform competitors in both profitability and growth. The use of a proactive niche market strategy in practice is examined in case studies of three global Swedish steel firms that have achieved above-average profitability over time. We propose, as a result of our analysis, the concept of the proactive niche market strategy as one that employs a mix of five key activities: focusing on the customers' customers; making the effort to become a preferred supplier early in the process; interacting with customers at multiple levels; extending the product offering by adding services; and focusing on the development of “adjacent” products, markets, and applications.
\end{abstract}

Keywords: niche marketing; proactive niche market strategy; activities; steel industry; case studies. 


\section{Introduction}

Many firms producing upstream commodity-oriented products in such mature industries as steel, paper, and petrochemicals are today facing increased global competition, not least from low-cost producers. One strategic avenue open to these firms to counter that challenge has been to pursue a "niche market strategy" (Toften \& Hammervoll, 2013). Increased competition has forced many traditional commodity-based industrial firms to upgrade their offerings, for example, from standardized bulk products to more specialized and customized products (Skarp \& Gadde, 2008), to better serve a smaller niche in the market. It is now more than three decades since Porter (1985) recognized the potential of focusing on narrow strategic differentiation and offering tailored offerings that meet the unique needs of customers. Rangan \& Bowman (1992) have since similarly advocated a strategy focused on niche markets as a way to avoid direct competition with low-cost, low-price rivals, especially in stagnant or even shrinking markets. The process of transitioning towards such a niche market strategy can be both costly and timeconsuming but it has the potential to generate returns and profits higher than those of bulkproducing competitors.

Hamlin, Henry, \& Cuthbert (2012) have noted, however, that niche strategies are treated in the marketing literature as primarily defensive countermeasures used by weaker players to build protective barriers, avoid competition with stronger players, and survive in a "regular" market while facing such threats as diminishing returns, increased international competition, overcapacity, and price deflation (Parrish, Cassill, \& Oxenham, 2006a, 2006b; Toften \& Hammervoll, 2013). This seems to hold true especially for firms in mature industries facing increased competition from low-cost and low-price rivals with both scale and scope advantages (Parrish et al., 2006a, 2006b). Recently, Boon, Moors, \& Meijer (2014) have discussed different processes and strategies for niche protection. Hamlin et al. (2012) and Parrish et al. (2006a) confirm that most niche market strategies could be categorized as defensive and recommend procedures for identifying, implementing, and maintaining such strategies effectively.

Contrary to the prevalent view of the niche market strategy as a defensive reaction, this paper proposes that it can be used as a proactive or even aggressive choice that, rather than allowing a firm to barely survive in the marketplace, can potentially enable it to outperform competitors in both profitability and growth. In accordance with the findings of previous research by Dalgic \& 
Leeuw (1994) and Toften \& Hammervoll (2013), we conceive of a niche market strategy as an applied initiative, used and defined by a set of activities.

The use of proactive niche market strategies in three global Swedish steel firms is examined by means of in-depth case studies, which illustrate how the five characteristic activities can enable firms to achieve above-average profitability over time. The Swedish steel industry, which was traditionally a mature bulk-producing industry but today consists of several niche players, serves as a fitting empirical context in which to develop an enhanced understanding of successful proactive niche market strategies.

In this study, we find that five activities underpin the concept of what we term a proactive niche market strategy: focusing on the customers' customers; making the effort to become a preferred supplier early in the process; interacting with customers at multiple levels; extending the product offering by adding services; and focusing on the development of “adjacent” products, markets, and applications.

The paper is structured as follows. Section 2 describes and discusses the concepts of niche and niche market strategy as developed in the published literature. Section 3 presents the chosen research methodology and section 4 presents the research setting. Section 5 then presents the generation and analysis of data for the three case firms and for the five key activities identified. The sixth and penultimate section takes a managerial perspective on the findings and discusses the practical implications for management. The final section, section 7, draws overall conclusions from the research study.

\section{The niche and niche market strategy concepts}

Although niche marketing and niche market strategy are popular contemporary concepts among both academics and practitioners, no generally agreed definitions of the concepts are found in the literature. Many of the definitions of "niche" discussed in the literature reviews by Toften \& Hammervoll (2013) and Dalgic \& Leeuw (1994) bear clear resemblances to traditional definitions of "segment". A niche can be seen as a "specific market segment" and "firms can choose to produce a single market offering targeted to a specific market segment (i.e., a niche strategy)” (Hunt \& Arnett, 2004, p. 17). Dalgic \& Leeuw (1994, p. 40) consider a niche to be “a small market consisting of an individual customer or a small group of customers with similar characteristics or needs”. In general, the definitions emphasize that a niche is a smaller (Stanton, 
Etzel, \& Walker, 1991), more focused (Philips \& Peterson, 2001), and often narrower (Toften \& Hammervoll, 2013) segment of a wider referral market. Kotler (2003) also notes that customers within a niche have a distinct set of needs and are willing to pay a premium to the firm that best satisfies those needs. Niches are therefore not static but can constantly be developed by identifying new needs of potential customers, needs that are currently not being satisfied by other market offerings. For example, Skarp \& Gadde (2008) demonstrate that niche steel companies can grow their specific niches by offering upgraded steel offerings to customers currently using standard steel. In that sense, it is possible to persuade customers to move from the standard referral market to the niche market segment. Hence, for the purpose of this paper, a niche is treated as a specific (as in focused, smaller, and narrower) market segment targeted by a firm's offerings.

Literature reviews by Toften \& Hammervoll (2013) and Dalgic \& Leeuw (1994) demonstrate that the great majority of studies analyzing niche market strategies emphasize their defensive aspects. Hamlin et al. (2012) have demonstrated that firms pursuing a niche strategy have often been viewed as weak, in decline, and unable to compete with stronger players in the market. Toften \& Hammervoll (2013) note that, given such an emphasis on defensiveness, several studies have underlined the need for weaker niche players to erect protective barriers as a way of avoiding competition with stronger players. The same authors have proposed this definition of a niche market strategy: "The process of carving out, protecting and offering a valued product to a narrow part of a market that displays differentiated needs” (Toften \& Hammervoll, 2013, p. 280). What is apparent even in this description is the defensive focus signaled by "protecting". From a business strategy perspective, traditional niche firms can therefore be seen as typical defenders (Miles \& Snow, 1978) focusing on smaller segments of the market, trying to maintain secure positions (Walker \& Ruekert, 1987), and sealing off portions of the market (Slater, Hult \& Olson, 2010). Both Dalgic \& Leeuw (1994) and Toften \& Hammervoll (2013) argue that niche market strategies can be used at both the strategic and the operative marketing decision levels.

Previous studies have identified various factors affecting the success of niche market strategies, perhaps the most important of which is the ability to build strong and long-term customer relationships (Dalgic \& Leeuw, 1994). According to Kotler (1999), among the key advantages of focusing on customers in a niche are the opportunities to get to know each customer more personally, to face far fewer competitors, and to earn a higher margin since the customers in the 
niche will often be willing to pay a premium for the niche marketer's expertise in meeting their needs. Both Toften \& Hammervoll (2013) and Dalgic \& Leeuw (1994) discuss numerous other reported benefits, such as enhanced profits, higher prices, increased sales, superior growth, improved market share, and increased competitiveness. Less frequently mentioned in the literature is more efficient value creation through improved attuning to customer needs (Toften \& Hammervoll, 2013).

\subsection{From defensive to proactive niche market strategy}

As we have seen, the niche market strategy is often portrayed as a form of defensive "pull marketing" in which management first identifies a niche market, then develops a product for it, and eventually seeks to protect it by raising a variety of barriers (Parrish et al., 2006a, Toften \& Hammervoll, 2013). Processes and strategies for protecting a niche have been proposed by, for example, Boon et al (2014).

One of the most serious potential challenges associated in the literature with the pursuit of a niche strategy is that change in the pattern of customer demand may reduce uptake of the niche marketer's products. According to Hamlin et al. (2012), previous research into niche market strategy has insufficiently emphasized this issue. Our review of the literature found only two studies considering that such a strategy might be carried out in a more proactive, even aggressive, manner and thereby enable enhanced growth and increased profitability (Hamlin et al., 2012; Gaudes, 2004). In the latter, the strategy of occupying multiple niches as a springboard for an aggressive move into a mainstream market is exemplified by the entry of a Japanese producer of heavy machinery into the North American market, for whom a single niche provided the means to gain an initial foothold from which to expand successfully into large sectors of the total market.

There seem to be very few studies in the literature of firms that have taken a strategic approach by actively seeking to drive a market niche, rather than simply protecting and defending it. It is possible to find some support for this proactive line of reasoning in the literature on strategic types (Miles \& Snow, 1978; Walker \& Reukert, 1987; Slater et al., 2010), in which the prospector type relies on proactive behavior that drives the market. A proactive niche actor ought to exhibit traits similar to those of a prospector (e.g. the identification and exploitation of new product and market opportunities) but, as they are niche actors and as such are defined by narrow 
focus and the existence of a core market, they also ought to exhibit some characteristics of a socalled differentiated defender (Walker \& Reukert, 1987) (e.g. continuous differentiation and reliance on a stable core market niche), especially perhaps in the particular context studied here, as capacity utilization and scale economies are pivotal concepts in the steel industry.

Though a number of benefits might well be realized by approaching niche market strategies from a defensive perspective, firms that do so risk becoming complacent and continually finding themselves in a race to the bottom in shrinking markets with decreasing margins. They also risk losing control of their marketing channels, due to their relatively limited engagement with customers or other downstream actors, as not only competitors but also such other actors as suppliers and customers become more powerful and innovative. A similar line of reasoning is proposed by Narver, Slater, \& MacLachlan (2004). They argue that for any business to create and sustain success, a responsive market orientation strategy is not sufficient. Rather, a proactive market orientation strategy plays an important positive role in a business's new-product success, for example, by reducing the risks inherent in relying on customers' best guesses as to new products and by lessening the impact of competitors’ parallel new product responses.

Contemporary niche market strategists can instead approach their strategy proactively by performing a new set of activities, the outcome of which can be expected to maintain leadership in the niche, drive the market, expand the niche focus, and sustain healthy growth. The case study analyses in this article focus on three firms using what we would define as a proactive niche market strategy, describing the activities they perform in pursuit of that endeavor.

\section{Method}

Qualitative in-depth case studies of three global Swedish steel firms were chosen for this study as the most appropriate method for examining the concept of a proactive niche market strategy. The case study method was chosen as the best means to capture this dynamic, complex, and context-bound process taking place in different firms within the same industry. Analysis of data collected from a variety of significant post-holders in three host firms allowed us to identify different actors and standpoints. This is, according to Eisenhardt \& Graebner (2007), an effective procedure for gaining new knowledge about a specific phenomenon. In particular, the case study method was expected to deepen our understanding of the contextual factors and underlying processes that enable a proactive niche market strategy. 
A central partner in the research project was the Swedish Steel Producers' Association, and this working relationship gave us a high degree of access to data both from the Association itself and from its member firms. The researchers were thereby often party to internal figures, pricing strategies, and other information that must remain unpublished due to its sensitive nature. The resulting richness of the data available for analysis significantly enhanced our understanding of what activities contributed to the success of the studied firms’ applied strategies.

\subsection{Data collection}

The study reported here was part of a larger three-year research project with the objective of identifying how Swedish steel firms might continue to develop their markets and offerings to create even greater value for their customers. The overall research project was divided into several sub-projects, one of which concentrated on the proactive niche market strategy and is the focus of this particular research. The benefits of being part of a larger research project included better access to key respondents and an improved understanding of contextual factors. The Swedish steel industry was seen as a fitting empirical setting in which to study niche market strategies, as this industry has moved from bulk production to being highly niche-focused. Furthermore, the chosen firms identify themselves as niche actors (for more on the empirical context, please see section 4).

A total of nine Swedish steel firms participated in the overall research project. As a first step, all firms were visited and initial interviews (the first round of interviews), based on a general interview guide focusing on overall challenges and opportunities, were conducted with senior managers within the firms (for an overview of the data collection process, please see appendix A). The purpose of these initial interviews was to improve our understanding of the firms, their businesses and environment, and the challenges and opportunities they face (for an overview of the interview guides, please see appendix B). These initial interviews, together with a focus group with all participating firms, enabled us to identify several areas of interest (subsequently forming the research sub-projects), where the area of niche market strategies was seen as being both a key challenge and a key opportunity for all participating firms. Based on the initial data collected, we determined three criteria, pertaining to niche market strategies, for selecting appropriate case study subjects from the pool of nine firms included in the ongoing overall research project. 
First, the firms had to have current experience of an applied niche market strategy and be able to demonstrate success in performing above the industry average in terms of such financial yardsticks as ROCE and total shareholder return as well as being market leaders in their respective niches. Second, for reasons of practicality, access to such key informants as the CEO and the Directors of Finance, R\&D, and Markets had to be readily available. Third, the chosen firms should display common characteristics in how they approached their respective niche markets. Our case selection was thus inspired by Yin's (2003) concept of literal replication in which the cases are chosen to corroborate each other. The sample selection can also be characterized as theoretical sampling rather than statistical sampling, in pursuit of analytical generalizability of the findings (Yin, 2003). These criteria yielded the three firms, denoted A, B, and $\mathrm{C}$, at the centre of the research reported here.

Given the focus of this research - niche market strategy - a second interview guide was developed based on the literature on B2B marketing, service marketing, and niche market strategy. The second round of interviews was then conducted in the three selected firms and subsequently collated and analyzed. These interviews were held with senior market managers, chief executives, and managers responsible for certain niche categories. In addition, a focus group was subsequently held together with representatives of the total pool of nine firms, in which data, analyses, and preliminary findings on the three selected niche firms were discussed and validated.

For a third round of interviews, a revised version of the previous interview guide (based on the second round of interviews and the literature) was used to further explore the issue of niche market strategies. This is in line with an abductive approach alternating between theory and the empirical phenomenon (Dubois \& Gadde, 2002; Dubois \& Gibbert, 2010). This interview guide provided a structural framework (generated from the literature in focus) for the interviews and its questions were relatively open-ended to begin with so as not to introduce bias (cf. Tuli, Kohli, \& Bharadwaj, 2007). When needed, the interviewing researchers asked follow-up questions to allow further exploration and to amass additional details on key areas.

Thirty interviews were conducted on site in the three firms. The rationale for this sample profile was to minimize the scope for bias inherent in relying on answers from a relatively small number of respondents, and to capture a rich diversity of inputs at various organizational levels with 
regard to the firms' applications of the niche market strategy. It furthermore permitted us to increase the validity of the information by means of triangulation (Yin, 2003). The respondents were high-level post-holders representing several different and distinct organizational groupings within the three firms: chief executives, finance directors, production directors, R\&D managers, business sector managers, senior market managers, technical sales managers, and those responsible for quality control. The data for analysis were primarily collected by face-to-face interviews, but other significant contributors to the total dataset were internal and external secondary source material (e.g. annual reports and confidential firm-internal data on profit margins) and conducted tours of the three sites lasting between one and three hours each. In a final focus group, our preliminary findings were presented and discussed with representatives of all nine firms. The rationale for the focus group approach was to validate and strengthen the findings of the study in terms of their practical value for both academics and practitioners in the field.

All interviews (in total 45) were semi-structured around the three interview guides (Gibbert, Ruigrok, \& Wicki, 2008; Yin, 2003). The focus group discussions enabled the researchers to discuss preliminary analyses and findings, strengthening the final analysis and validating the results (Matthyssens \& Vandenbempt, 1998; Stewart \& Shamdasani, 1990). In the discussions, a spirit of openness and honesty was engendered by the high level of trust in the relationships between the researchers and the respondents' organizations and by the fact that none of the participating firms was in direct competition with any other.

\subsection{Data analysis}

The interviews were generally audio-recorded and later transcribed. Three were conducted by telephone on account of the respondents' travel commitments, so interviewer note-taking had to replace recording. One respondent asked to remain anonymous, so that interview could not be recorded on ethical grounds. The respondents were given the opportunity to review the transcripts of the recorded interviews, or the notes taken during unrecorded interviews, in order to minimize misunderstandings and errors of transcription (Gibbert et al., 2008). Our method shares many similarities with comparative text analysis, in starting with a close reading of every transcribed interview in order to be certain about the nature of the key activities under discussion and about the general themes explored in the conversations. Interviews were later individually 
coded for content and then read in relation to one another, allowing general patterns to be detected (Strauss \& Corbin, 1990) in a clustering process that ultimately identified five key activities forming the basis of the host firms’ proactive niche market strategies.

Following the methodological lead of Eisenhardt (1989) and Yin (2003), our process of analysis and interpretation was carried out as a prelude to cross-case comparisons and pattern matching procedures. Some activities were found to be central to the firms' success, while others were peripheral. Two researchers conducted the initial analysis of the data collected from the host firms before comparing and synthesizing their process notes at a later stage (Yin, 2003). An iterative process of switching sequentially between empirical results and theoretical inputs generated and developed the new conceptual framework presented in this paper. The structured approach taken enhances the validity and robustness of the results (Yin, 2003). Other input from the focus group discussions and secondary information sources furthermore helped us to triangulate and validate the analyses and findings.

\section{Research setting}

\subsection{The steel industry in Sweden ${ }^{1}$}

The steel industry in Sweden comprises in total 20 firms with 29 substantial production facilities. Many of these are the present-day representatives of several hundred years of iron and steel production in Sweden. It remains an important national industry today, employing roughly 17,000 people directly and creating additional tens of thousands of jobs in indirect employment. Most of the Swedish steel output is exported to about 140 countries, making many of the individual firms highly global players. The total value of the industry's exports was approximately 3.8 billion Euros in 2013.

In recent decades, the Swedish steel industry has undergone major restructuring. Its constituent firms have specialized in different niches, most manufacturing highly finished steel products for a variety of export markets. Sweden's steel firms have continuously developed new steel grades and products and, in several cases (including the three case firms), the firms are world leaders in the development and production of advanced steel offerings in their specific niches. Most of the products that the steel firms manufacture - e.g. plate, strip, wire, rod, profile, and tube steel - are

\footnotetext{
${ }^{1}$ This section is based on information from the Swedish Steel Producers' Association.
} 
destined for export. Since the Swedish steel industry concentrates on specialized steel grades and products, steel of more basic quality is imported. In fact, a major part of all steel used in Sweden, for example, structural steel for construction, is imported.

Hence, to retain their positions in the global market, Swedish steel firms have increasingly focused their production on ever more advanced qualities of steel. This is exemplified by the fact that their share of so-called alloy steel - which also includes stainless steel - has steadily increased. At present, around 60\% of the total Swedish production comprises alloyed steel. This is an exceptionally high proportion compared with the rest of the EU, and with the US and Japanese steel industries, where alloy steels comprise only approximately $10-15 \%$ of the total production. In developing industry markets, that share is even lower. This shift to advanced steel has accelerated since 1990 when non-alloyed steel still comprised approximately 55\% of the total output in Sweden.

The Swedish steel industry expanded significantly up to the 1960s, but in the 1970s the emergence of the steel crisis led to significantly reduced demand. As in many other Western countries, the Swedish steel industry was forced to reduce output and many plants were closed. Many firms were forced either to shut plants or to merge with national competitors to survive in the shrinking market. This process forced the surviving plants to concentrate on different products to reduce the output and decrease national competition. The result was that, by the end of the 1980s, Swedish steel firms had largely ceased to compete with each other at the national level. By focusing on their respective niches, the firms could become competitive on a global market, with the result that many Swedish steel firms are today market leaders within their respective niches.

\subsection{The case firms}

The case firms - firms A, B, and C - are all market-leading niche actors on the global steel market. Firm A's niche is metal powder and its position within the niche is as a market leader with approximately $30-40 \%$ of the total market share. Firm B is a market leader within the niche of high-quality wire used, for example, in valve springs and transmissions, and it accounts for approximately $30-40 \%$ of total sales within the niche. Firm C is a market leader within the niche of tool steel and its sales account for approximately $30-40 \%$ of the niche market. Table 1 briefly outlines the characteristics of the three case firms. 
- Insert table 1 here -

\section{Findings of the case studies: key routes to a proactive niche market strategy}

Contrary to the general tendency noted in the literature to perceive a niche market strategy as largely defensive, the case study firms were approaching the strategy much more proactively by setting business goals related to the growth and expansion of their portfolios of offerings, and to profit margins and the management of customer relationships. Proactive niche marketers perceive their niche status and define their niche strategy in terms of two main drivers: the application areas in which their customers use the supplied products and the type of products they provide to those customers.

Figure 1 depicts the five key activities based on which the three firms were found to have built their proactive niche market strategies.

- $\quad$ Insert figure 1 here -

Of those five activities, focusing on customers' customers and achieving preferred supplier status are mainly externally oriented towards the downstream actors in the marketing channel, in the marketplace. The orientation of interacting with customers at multiple levels, extending the service offering, and securing future growth through “adjacent” business opportunities is mainly internal, towards business development with a primary focus on the product, the portfolio, and market development, respectively. All five activities are thus proactive but provide different inputs, the first two being geared to a proactive influence on external factors - their customers' markets and the choices made by downstream actors - and the second two aiming for a proactively influence on internal processes - product innovation, portfolio extensions, and the development of new businesses and associated offerings.

All case study firms used the entire set of activities and identified them as key drivers of their proactive niche market strategy, though to different degrees, and as important factors in their business performance. The five activities are now each discussed in more detail.

\subsection{Focusing on customers' customers}

A key element of a proactive niche market strategy is broadening the scope of the corporate business focus. The case studies indicate that the host firms have extended their market horizons and now address the entire marketing channel in attempting to grow their niches and expand 
their business opportunities, most notably to encompass their customer's customers (typically such OEMs as an automotive manufacturer). As one respondent put it:

Our firm steps in and manages the interaction with the customer's customer and manages the relationship and the entire contract really, since the customer is often too small to manage both the particular contract and the market.

\section{Sales director}

This strategic activity is especially important for all the host firms since none of them manufactures products sold directly to an OEM. In practice, several stages in the marketing channel intervene before a certain type of product is used in a final manufacturing or assembly process.

Influencing the entire marketing channel is achieved in several different ways, such as by arranging technical seminars and providing training activities for OEMs, one firm going so far as to develop in-house sales training in the kinds of approaches that are necessary in the firm's indirect selling relationships with OEMs. Its senior market manager explained that:

What we are now actively trying to do, and also have attempted previously, is to really train certain chosen salespeople in order for them to become particularly competent in approaching actors further downstream [in the marketing channel] who can specify products [to OEMs].

\section{Senior market manager}

A niche market firm can make contact with a customer's customer, such as an OEM, either directly with a proposal for a new technological solution or jointly with its own customer, thereby building not only its own reputation and niche product portfolio but also that of the intermediaries in the marketing channel. One CEO underlined the importance of this activity thus:

The prerequisite for our operation is that we maintain a connection with the customer’s customer.

CEO 
By taking responsibility for influencing the customers' customers as well as providing input into their development processes, the host firms could achieve several benefits. The first of those was the potential to grow with their customers, as this respondent explained:

We create growth for their [i.e. the customer's] customers. This is what we can offer. And by activities geared towards the end user we actually can, as we call it, grow their [i.e. the customers'] businesses.

\section{Senior market manager}

The second benefit would lie in the niche marketers' superior knowledge of steel in general and of their own steel products and applications in particular, enabling them to propose improved processes and applications at the customer and industry levels, including completely new ways of solving specific problems.

One host firm, a market leader in a radical new technology with special product and process characteristics, takes an even more proactive approach. It works diligently to influence the entire value system by piloting the development of new types of products that could influence actors all the way to the end-consumer. This technology requires a different process, with respect to downstream actors, than does the established technology in the industry. In this sense, this particular niche firm even has the potential to transform the entire marketing channel. Kumar, Scheer, \& Kotler (2000) have suggested that market-driving firms delivering radical business innovation gain a more sustainable competitive advantage by delivering a leap in customer value through a unique offering. In this context, the respondent argued that:

It is difficult for us to grow in terms of market share [in our existing niches]. That means that we must, in some way, be able to address the growth of the entire market to realize our own growth.

\section{Senior market manager}

Another major advantage of focusing on the customers' customers is that the sales organization is forced to become much more proactive. Rather than acting as passive receivers of orders, as was the case previously, the firms have striven to become sellers of added value through training programs and the recruitment of new personnel. They have thus been able to move away from the traditional industry practice of simply distributing a price list to customers. A further key 
element of this strategy is the adding of extra value globally by means of wholly-owned local subsidiaries, which is not always the norm for this industry. These can develop close relationships with both customers and end users, and in some cases add even more value through their own customer-specific activities and services. This is a significant issue for niche firms operating in the global marketplace: being able to grow their sales while still being able to tailor their offerings to local demand.

\subsection{Achieving preferred supplier status}

To establish a position as a niche player, whether defensive or proactive, a firm needs to demonstrate a strong brand that customers will associate with superior knowledge and better offerings. As one CEO put it:

At the commodity end of our product range, we get a small price premium because the customer knows that we can be trusted. This is the strength of our brand. Looking at the launch of new products, the customer knows that they are good [because they trust the brand] and are therefore willing to risk trying the new product ... they know that we have tested it in a certain way, making sure it is good.

CEO

In our study, the niche players' corporate brands had, over a long period of time extending in two cases to more than a hundred years, built reputations for very high-quality, in-depth knowledge of the steel industry and for dedication to steel products. The focus on achieving preferred supplier status is also reflected in their various customer-engaging activities: mainly selling, but also participating in trade fairs and the like, and in particular circumstances acting as expert consultants. Many respondents argued that it was a great advantage in meetings with customers to have a strong heritage in which historical credibility is combined with a reputation for supplying the highest-quality steel available for a particular application. Branding has become increasingly important in business-to-business marketing in recent decades; for example, Kotler \& Pfoertsch (2007) found that in long-term industrial branding strategies, the performance of the B2B brand and a firm's overall business performance are all positively correlated with rising share prices. 
The focus on achieving preferred supplier status was further found to enable all three firms to achieve listing by OEMs (located downstream in the marketing channel) as preferred suppliers. All firms explained that they had on several occasions over time attempted to influence the end user to specify that its supplier (that is, their customer) should use their products in its own production. For example:

... but what we try to influence is their [i.e. the customer's] customer, to get it specified ...

\section{Senior market manager}

One example of this process operation is Firm C, which produces steel for the manufacture of tools. It has been able to achieve specification by two of the world's market-leading producers of consumer electronics, even though those firms are three steps ahead of it in the marketing channel. This is a major advantage in the steel industry, which is driven in part by quality standards that are set lower than apply to the premium brands of the niche manufacturers. To achieve preferred-supplier status, niche market players thus have to occupy a front-of-mind position not only with respect to their own customers but also their customers' customers or even their customers’ customers’ customers.

\subsection{Interacting with customers at multiple levels}

Customer interaction in the host firms was found to be multi-level with touch points in the sales function and, atypically for production-focused firms, in R\&D and the production function. As one respondent put it:

We try to build relationships with customers throughout the organization, with production, R\&D, [and quality].

Senior quality manager

Van Raaij \& Stoelhorst (2008) argue that these interactions, part of what is described as a system of high network embeddedness by Echols \& Tsai (2005), are necessary for the acquisition of information for both market and product development. Without knowledge based on that information, niche market firms run the risk of stagnation and narrow horizons, and consequently of not being able to maintain the level of proactivity required. Since customers have direct access to suppliers at up to three levels removed, not only with the sales function but also with the R\&D 
and production functions (including the "quality” function identified separately by the Senior quality manager in the above quotation), many of the firm’s activities are driven and prioritized by this feedback “from the horse's mouth”, so to speak. Furthermore, the process gives access to deep customer-related and application-specific knowledge, as well as providing the opportunity to build customer relationships at three levels of customer interaction - necessary preconditions for becoming a proactive niche actor.

With regard to the first of the three levels, the host firms' sales organizations had undergone major changes in order to disseminate this knowledge-driven approach, and to enable an increased focus on value and customer-specific solutions. At one, a majority of the sales force had been replaced or relocated in pursuit of a shift to a more proactive culture. This phenomenon has also been noted in other industries facing similar challenges (Ulaga \& Reinartz, 2011). At a second firm, extensive training programs had been developed to build an active sales organization that exhibited high levels of competence in value-based selling and knowledge of both the firm's product and service portfolio and of the customers' applications. The shift to a more value-based approach had been especially challenging and training has been suggested as a necessary precondition for realizing such a shift (Terho, Haas, Eggert, \& Ulaga, 2012). These initiatives were relatively new and had been launched as the host firms emphasized their proactive niche market strategies.

At the second level, the production organization also interacted directly with customers, thereby infusing also this function with customer knowledge. This interaction was primarily initiated by customer feedback regarding faulty products and the underlying production processes. Two important cornerstones of the ability to be a proactive niche player are deep knowledge of the core product, steel, and world-class competence in the various applications in which customers use the supplied steel products. As one respondent put it:

The better we get at understanding the needs of the customers and their processes, the better we get at developing products that go hand in hand with their processes and at being able to help them when they run into problems.

\section{Senior market manager}

At the third level, all three host firms had their own R\&D departments and laboratories, with responsibilities including new product development, staffed by highly qualified personnel and 
equipped with advanced technical equipment to perform product development and materials research. They also gave their customers access to their expertise and competences by testing materials, co-creating solutions, and carrying out other tailored projects. These services were frequently delivered free of charge, being viewed as one component of the premium level of their product pricing.

Such multi-level interaction can, to an extent, achieve a market strategy of both product leadership and customer intimacy (Treacy \& Wiersema, 1995) and enable avoidance of the commoditization trap (Matthyssens \& Vandenbempt, 2008). This interaction was also found to have enabled the host firms to enhance existing customer knowledge and provide a portfolio of competences and associated high-quality products capable of outperforming both those of competitors with greater market reach and those of smaller local niche firms lacking a proactive strategy. They were furthermore able to achieve more effective processes of product innovation and materials technology development, which in turn delivered the potential for a higher rate of new or improved products (or both), better suited to existing customers and their applications, and for the development of such new application areas as “adjacent” products and markets. The importance of customer knowledge in product development in complex marketing channels has been previously underlined by McDermott (1999) and Rijsdijk \& Van den Ende (2011). A senior market manager at one of the firms stated:

We have many employees, for example, technical sales persons, who visit customers on an almost daily basis all over the world, meaning that we gather a lot of insights from customers ... from these we can come up with stuff at our R\&D department ... it is very rarely that someone just sits here and gets hit by a brilliant idea - bang; instead, they [i.e. the ideas] come from outside.

\section{Senior market manager}

Concrete examples involving multiple levels are the customized heat and surface treatments that are being carried out at various production sites, located close to the customers, globally. These treatments involve the production organization but have been developed by the R\&D department through customer interactions, and are sold by the sales force through training and education activities geared towards customers. 
Enabling customer insights to be channeled through multiple interactions with different business functions within the supplying firm is, as emphasized above, an important effect of the multilevel approach to customer interaction.

\subsection{Extending the service offering}

The host firms, their customers, and the whole industry perceive their business as highly productoriented, with a traditionally strong focus on production and production-related costs. However, primarily to justify a premium price and build relationships (e.g. due to the added value the service component provides), the niche marketing firms in our study were seen to be shifting their focus from production to other areas, such as services, logistics, business development, and sales training, and consequently had an increasing number of services in their portfolios.

Interestingly, there is also emerging interest in the three host firms in services as a potential area for growth and revenue generation.

In other industries, this extension into new services has been referred to as "service infusion" (Kowalkowski, Kindström, Brashear, Brege, \& Biggemann, 2012; Ostrom, Bitner, Brown, Burkhard, Goul, Smith-Daniels, Demirkan, \& Rabinovich, 2010) or “servitization” (Baines, Lightfoot, Peppard, Johnson, Tiwari, Shehab, \& Swink, 2009; Vandermerwe \& Rada, 1988). These infused services range from specified logistics offerings, such as different delivery options and warehouse services, to more loosely defined material-testing services, co-creation of certain offerings, and even customer-specific R\&D work conducted, for example, in the laboratories of the host firms. These findings validate those reported by Ulaga \& Eggert (2006) that such aspects of the present-day service relationship as service support, personal interaction, supplier knowhow, and supplier ability to improve a customer's time to market are often the core differentiators, rather than price.

A common characteristic of these services is that, with very few exceptions, the steel firms do not charge for them. Several of the host firms instead emphasized the brand- and relationshipbuilding benefits of providing expert knowledge and being perceived as a trustworthy partner ready to help customers when they have problems or queries:

An advantage for us is that we have resources to commit if there are problems ... this is something that the customers really appreciate. 


\section{Senior quality Manager}

We are damned good at [pause] ... the few times we make mistakes, we are very good at correcting them. That is, making sure that we help the customer to solve their practical problem but also trying to learn something from the mistakes. And that part is important. And the customers know this: they know that if they run into problems we will fix them.

\section{Senior market manager}

The services provided can be categorized as knowledge-based and activity-based. The former category not only creates value for customers but also deepens working relationships with them, thereby giving the niche operator direct access to detailed customer information not accessible to other actors. This is close to the notion of “process-oriented (customer) services” (Mathieu, 2001; Ulaga \& Reinartz, 2011; Kindström \& Kowalkowski, 2014). The knowledge of the customer thus created can be used in developing and customizing offerings, in product development processes, and in developing application-specific knowledge. This last is a process of becoming even more knowledgeable and more attractive as a supplier, linking the supplier closer to the customer, thus making the customer less inclined to change suppliers due to the added value provided by the (free) services. All the host firms asserted that the services had further led to customer loyalty and had secured future product sales. That is, these processoriented services have an indirect effect on a firm’s profitability and turnover. As two respondents remarked:

We do not charge extra for it; instead, it is a way to open up the playing field for selling steel.

Senior market manager

We almost never charge for [knowledge-based services].

\section{Senior market manager}

Activity-based services, closely related to what Mathieu (2001), Ulaga \& Reinartz (2011), and Kindström \& Kowalkowski (2014) have called "product-related services”, are those that the host firms do generally charge for (with the exception of logistic-based services discussed below). They are activities that centre on the provision of such additional services as heat treatment of 
materials and tailor-making steel products to match customer requirements, which add very tangible value to the core product and can be carried out at the originating production site or at a local facility near the customer location. This implies that the host firms would need to have access to local competence and equipment to deliver those services, which is in itself a competitive advantage that competitors can imitate only with difficulty and thus cements niche dominance in local markets globally. Two did have that access; the third did not at this moment.

One important class of activity-based service is those relating to logistics - significant because steel-based niche products can be atypically bulky for transport and warehousing. Such services rarely provide a competitive advantage, however, since more or less all actors in the business must and can provide them.

\subsection{Securing future growth through “adjacent” business opportunities}

The successful niche players in this case study have dedicated time and resources to the proactive development of their offerings by finding new niches and applications in so-called “adjacent” markets (Zook, 2004; Treacy \& Sims, 2004) that permit them to avoid undue reliance on existing applications and customers. The main motive is to ensure future, organic growth and to stay ahead of the competition, but a strategic rationale is also to find beneficial ways of making use of in-depth knowledge that either already exists or has been developed through multi-level interaction with firm customers. Two CEOs among the respondents put it this way:

We need to find adjacent areas to our existing ones in order to be able to grow. It is a challenge but also a necessity. Not least since we can see future decline in our current most important market area.

\section{CEO}

Looking at our firm over forty years, we have continuously shifted the low end, the commodities, from our product range and added new products at the high end, and have climbed in that way.

CEO

They are thus describing a conscious, proactive focus on the development of adjacent products and markets, to avoid becoming locked-in and defensive, which can lead to a detrimental emphasis on only penetrating existing markets. This stands in contrast to the findings of previous 
studies of niche market strategies, in so far as such defensiveness has been identified by Toften \& Hammervoll (2013) as one of the potentially most challenging pitfalls of a traditional niche market strategy. This is especially important for the host firms since a significant part of their sales are to the highly cyclical automotive industry (see Table 1).

The exploration of new potential markets and customers (as opposed to the exploitation of existing products and markets through incremental product and process innovations) (cf. Day, 2006) occurs mainly in business areas that are relatively close to the existing applications of a firm's products. Often, such adjacency developments are carried out in a co-creation process with lead customers. For example:

We have worked with these firms [i.e. customers and end users] when they developed their processes, so we are in there looking at what is needed, at what types of steel products are needed. So we make sure that we are involved in the entire chain and then, when they start selling their machines, they know what steel products they need.

\section{CEO}

The starting point of such close collaboration is often a combination of deep knowledge of steel, steel production, and customers' applications areas, effectively combining product and market knowledge. Day (2006, p. 13) argues that "strategies for pushing the boundaries of a business into adjacent products, markets, channels, or geographies are most successful when they combine inside-out and outside-in thinking”. The outcome is the capability to draw on highly skilled resources throughout the firms, using them to meet new market challenges.

Firm A has gone the furthest in this respect by developing a "pilot facility" aiming to push the limits of the range of uses its customers can make of its primary product. It has invested, in that facility, in machinery that is equivalent to, if not superior to, that used by its customers. It is thereby able to not only develop its own market offerings but also its customers' offerings, within adjacent application areas not previously relevant to its core products. For firm A, it is especially important to invest in product and market development and expand their application range, since their primary product, metal powder, may enable new production processes and techniques in the customers' businesses, and as such drive sales. 


\section{Managerial implications}

The key activities identified in the three case studies as underpinning a niche market strategy can, by guiding managers towards essential actions and decisions, encourage its proactive and long-term adoption and thereby deliver better performance and competitive advantage. Our respondents asserted that this proactive exploitation of niche markets had delivered several important benefits: higher profit margins, deeper customer knowledge, greater customer loyalty, stronger brand equity, and a more powerful position in the marketing channel. Table 2 describes the essential managerial actions associated with the five key activities identified in our analysis of the respondents' comments and identifies the implications of each for the use of a proactive niche market strategy in practice. It also outlines typical key managerial actions for putting the different activities to work in practice.

- $\quad$ Insert table 2 here -

It might seem a daunting task for a niche firm that is not currently proactive in its strategy to address all the listed activities simultaneously. The host firms have been implementing several activities for many years to achieve their current level of proficiency. They have found that those activities are often mutually reinforcing, in that focusing on one activity can increase the effectiveness of another. For example, by focusing on the customer's customer in the marketing channel, a firm might also increase its ability to find opportunities for “adjacency” development as well as to achieve preferred supplier status.

Many manufacturing firms, like the three global steel firms studied, provide such additional services as logistics, installation, upgrading, training, and support services. One relatively concrete first step towards extending the total service offering is to map the existing services. The findings of this study indicate that activity-based services can be the "low-hanging fruit" attracting customers to the idea of paying for additional services, after which the total portfolio of offerings can be extended. The first step can often be more difficult in the case of knowledgebased services. For example, neither the customers nor the suppliers in the three case studies seemed to have had any interest in paying for or charging for service offers. The managerial focus should therefore be on ways of understanding and communicating the indirect impact and value of such services on sales of the manufactured product and in future development of the offering. 
When considering the managerial implications of implementing the key aspects in practice, it was noticed that several of them demanded some kind of change in sales force operations if the proactive niche market strategy was to be effective in selling value and transforming the marketing channel. For example, a firm might usefully change its focus from simple "price-list distribution” towards recruiting new staff and establishing relevant training programs.

A first crucial step for a management aiming to move towards a proactive niche market strategy is to establish the starting points of their firm, the particular marketing channel to which it belongs and the industry of which it is a part, given the high likelihood that various contingency factors will determine where change will most readily be accepted. A second step would be to focus on present and future customer relationships, since those are the key to success in developing the firm's external focus and its ability to transform its marketing channel and market niche. This can be a particular challenge, given that recent research on niche market strategy by Toften \& Hammervoll (2013) has found that most niche firms are in mature industries that are, or at least traditionally have been, highly production oriented.

\section{Conclusions}

\subsection{Theoretical implications}

The concept of a niche market strategy has until now generally been seen as a means of fending off more powerful competitors and thereby ensuring a firm’s survival (Dalgic \& Leeuw, 1994; Toften \& Hammervoll, 2013). The fear that change in the pattern of customer demand may reduce uptake of the niche marketer's products is one of the most serious potential challenges associated in the literature with the pursuit of a niche strategy, and previous research has insufficiently emphasized this issue. The host firms in the research study reported here approach their niche market strategies from an altogether more proactive stance, executing a mix of five key activities focused on growth and market development. The firms implementing a proactive niche market strategy are, as discussed, carrying out a different set of strategic activities (or decisions) than is typically the case for traditional niche actors. In effect, they can be seen to be redefining the characteristics of the niche actor.

The five activities identified in this research define a new, more proactive niche market strategy, or even a new strategic type (Olson, Slater, \& Hult, 2005), that resembles that of the archetypical prospector as opposed to the typical niche actor acting as a defender (Miles \& Snow, 1978; 
Walker \& Reukert, 1987). In particular, employing specialists with detailed knowledge of steel and its applications and working closely with (lead) customers are parallels between a proactive niche market strategy and the archetypical prospector business strategy. The proactive niche actors studied here, however, also exhibit certain characteristics of analyzers, most prominently, the focus on traditional core steel products and markets, and of defenders, in their endeavor to retain customers through superior service and a customer orientation (Olson et al., 2005). These findings are also linked to recent research on context-specific contingency factors (e.g. strategy, structure, and environment) regarding strategy types to explain firm performance (Olson et al., 2005; Slater et al., 2010).

Our host firms are above-average performers in the Swedish steel industry that stand to reap several benefits from a proactive niche market strategy. Robinson, Clarke-Hill, \& Clarkson (2002), for example, argue in a study of the bulk chemical industry that an increased focus on relationship management in the supply chain and extending the offering into associated services could indeed be viable routes to competitive advantage in a commoditized environment such as the steel industry. Similarly, Skarp \& Gadde (2008) have argued that the interdependences between sellers and buyers must be treated as the cornerstones of such firms' strategies if they are to succeed in creating value and upgrading their offerings.

Adding to the findings of previous research in the field of services, our study has found that the combination of a basic product plus relevant services can play a pivotal role in increasing competitiveness and facilitating future growth. For the host firms studied, the added services are a prerequisite to being proactive niche players, embodying specialist knowledge, building the brand, and ultimately seeking to "lock out" the competition. These services, and the added value they provide, consequently play an important role in building long-lasting relationships with the customers. One advantage emanating from this is that the services enable the supplier to engage more closely with the customers, creating in-depth knowledge as well as establishing multi-level interaction points between the firms.

Finally, from a theoretical point of view, it is also interesting to note that a proactive niche market strategy expands the traditional dyadic supplier-customer perspective to a "dyad plus one”, effectively permitting the engagement of downstream actors. That is, successful proactive niche firms extend their system boundaries to include downstream actors in their "co-creation" 
of the offering in concert with their customer's customers, in their perception of the market, in their sphere of interaction, and in the five key activities performed. In that sense, those activities and, especially, the proactivity underpinning them, can be seen as exemplifying the mechanisms and processes of value co-creation within multi-actor systems, as discussed by Vargo (2008) and Vargo \& Lusch (2006, 2011).

\subsection{Future studies and limitations}

Further research might usefully evaluate and validate the performance of the identified mix of the five key activities that define a proactive niche market strategy. Especially interesting is the link to current developments in research into strategy types and the implications of various contingency factors (see e.g. Olson et al., 2005; Slater et al., 2010).

An important limitation of the study is that it focused on a single industry. As a logical extension of this research, investigation of the mix in other industries and sectors should yield results with interesting implications for future research. Other mature industries such as energy, pulp and paper, and chemicals are all, like the steel industry, characterized by relatively homogenous bulk-oriented products and by strategic challenges regarding growth, earnings, and profitability. Hence, extending future research to these industries may add additional insights capable of either confirming or modifying the findings of this study.

A second limitation of the study relates to the measurement of the niche firms' performance. The operating assumption that the five key activities are necessary and contribute to stronger corporate performance is matched by a strong conviction among the three participating firms and their financial data, but the research did not explicitly measure that outcome. Future research could elucidate the link between that proactive application of niche marketing and corporate performance. Such future topics of study could enhance our understanding of the five activities and shed new light on the context-specific issues in the present research. 


\section{IMM Manuscript 14-515}

\section{References}

Baines, T., Lightfoot, H., Peppard, J., Johnson, M., Tiwari, A., Shehab, E., \& Swink, M. (2009). Towards an operations strategy for product-centric servitization. International Journal of Operations \& Production Management, 29, 494-519.

Boon, W., Moors, E., \& Meijer, A. (2014). Exploring dynamics and strategies of niche protection. Research Policy, 43, 792-803.

Dalgic, T., \& Leeuw, M. (1994). Niche marketing revisited: concept, applications and some European cases. European Journal of Marketing, 28, 39-55.

Day, G. S. (2006). Closing the growth gap: Balancing "big i" and "small i" innovation. Market Science Institute Reports, Number 06-121, Cambridge, MA: Marketing Science Institute.

Dubois, A., \& Gadde, L., E. (2002). Systematic combining: an abductive approach to case research. Journal of Business Research, 55, 553-560.

Dubois, A., \& Gibbert, . (2010). From complexity to transparency: managing the interplay between theory, method and empirical phenomena in IMM case studies. Industrial Marketing Management,39, 129-136.

Echols, A., \& Tsai, W. (2005). Niche and performance: the moderating role of network embeddedness. Strategic Management Journal, 26, 219-238.

Eisenhardt, K. M. (1989). Building theories from case study research. Academy of Management Review, 14, 532550.

Eisenhardt, K. M., \& Graebner, M. E. (2007). Theory building from cases: opportunities and challenges. Academy of Management Journal, 50, 25-32.

Gaudes, A. (2004). The skinny on being narrow: a longitudinal study on the influence of niche-width in the presence of market turbulence. Journal of Comparative International Management, 7, Available at: http://journals.hil.unb.ca/index.php/JCIM/article/view/456.

Gibbert, M., Ruigrok, W., \& Wicki, B. (2008). What passes as a rigorous case study? Strategic Management Journal, 29, 1465-1474.

Hamlin, R., Henry, J., \& Cuthbert, R. (2012). Acquiring market flexibility via niche portfolios: the case of Fisher \& Paykel Appliance Holdings Ltd. European Journal of Marketing, 46, 1302-1319.

Kindström, D., \& Kowalkowski, C. (2014). Service innovation in product-centric firms: a multidimensional business model perspective. Journal of Business \& Industrial Marketing, 29, 96-111.

Kindström, D., \& Kowalkowski, C. (2009). Development of industrial service offerings: a process framework. Journal of Service Management, 20, 156-172.

Kotler, P. (1999). Kotler on marketing: how to create, win, and dominate markets. New York: The Free Press.

Kotler, P., \& Pfoertsch, W. (2007). Being known or being one of many: the need for brand management for business-to-business (B2B) companies. Journal of Business \& Industrial Marketing, 22, 357-362.

Kowalkowski, C., Kindström, D., Brashear, T., Brege, S., \& Biggemann, S. (2012). Service infusion as agile incrementalism in action. Journal of Business Research, 65, 765-772.

Kumar, N., Scheer, L., \& Kotler, P. (2000). From market driven to market driving. European Management Journal, $18,129-142$.

McDermott, C. M. (1999). Managing radical product development in large manufacturing firms: a longitudinal study. Journal of Operations Management, 17, 631-644.

Mathieu, V. (2001). Product services: from a service supporting the product to a service supporting the client. The Journal of Business and Industrial Marketing, 16, 39-61.

Matthyssens, P., \& Vandenbempt, K. (1998). Creating competitive advantage in industrial services. Journal of Business and Industrial Marketing, 13, 339-355.

Miles, R., E. \& Snow, C., C. (1978). Organizational Strategy, Structure and Process. New York: Mc- Graw-Hill.

Narver, J. C., Slater, S. F., \& MacLachlan, D. L. (2004). Responsive and proactive market orientation and new - product success. Journal of Product Innovation Management, 21, 334-347.

Olson, E. M., Slater, S. F., \& Hult, G. T. M. (2005). The performance implications of fit among business strategy, marketing organization structure, and strategic behavior. Journal of Marketing, 69, 49-65.

Ostrom, A. L., Bitner, M. J., Brown, S. W., Burkhard, K. A., Goul, M., Smith-Daniels, V., Demirkan, H., \& Rabinovich, E. (2010). Moving forward and making a difference: research priorities for the science of service. Journal of Service Research, 13, 4-36.

Parrish, E. D., Cassill, N. L., \& Oxenham, W. (2006a). Niche market strategy for a mature marketplace. Marketing Intelligence \& Planning, 24, 694-707. 


\section{IMM Manuscript 14-515}

Parrish, E. D., Cassill, N. L., \& Oxenham, W. (2006b). Niche market strategy in the textile and apparel industry. Journal of Fashion Marketing and Management, 10, 420-432.

Philips, J.C. \& Peterson, H.C. (2001), "Segmenting and differentiation of agri-food niche markets: examples from the literature”, staff paper , Michigan State University, East Lansing, MI.

Porter, M. E. (1985). Competitive Advantage (1st ed.). New York: The Free Press.

Rangan, V. K., \& Bowman, G. (1992). Beating the commodity magnet. Industrial Marketing Management, 21, 215224.

Rijsdijk, S. A. \& Van den Ende, J. (2011). Control combinations in new product developments projects. Journal of Product Innovation Management, 28, 868-880.

Robinson, T., Clarke-Hill, C.M., \& Clarkson, R. (2002). Differentiation through service: a perspective from the commodity chemicals industry. Service Industries Journal, 32, 149-166.

Skarp, F., \& Gadde, L-E. (2008). Problem solving in the upgrading of product offerings - a case study from the steel industry. Industrial Marketing Management, 37, 725-737.

Slater, S. F., Hult, G. T. M., \& Olson, E. M. (2010). Factors influencing the relative importance of marketing strategy creativity and marketing strategy implementation effectiveness. Industrial Marketing Management, 39, 551-559.

Stewart, D. W., \& Shamdasani, P. N. (1990). Focus groups: Theory and practice. Thousand Oaks, CA: Sage Publications.

Stanton, W.E.J., Etzel, M.J. \& Walker, B.J (1991). Fundamentals of Marketing. McGraw-Hill, New York, NY.

Strauss, A., \& Corbin, J. (1990). Basics of qualitative research: Grounded theory procedures and techniques. London: Sage.

Terho, H., Haas, A., Eggert, A., \& Ulaga, W. (2012). 'It's almost like taking the sales out of selling'- towards a conceptualization of value-based selling in business markets. Industrial Marketing Management, 41, 174-185.

Toften, K., \& Hammervoll, T. (2013). Niche marketing research: status and challenges. Marketing Intelligence \& Planning, 31, 272-285.

Treacy, M. \& Wiersema, F. (1995). How market leaders keep their edge. Fortune, 131, 52-57.

Tuli, K.R., Kohli, A. K., \& Bharadwaj, S.G. (2007). Rethinking customer solutions: from product bundles to relational processes. Journal of Marketing, 71, 1-17.

Ulaga, W., \& Eggert, A. (2006). Value-based differentiation in business relationships: gaining and sustaining key supplier status. Journal of Marketing, 70, 119-136.

Ulaga, W., \& Reinartz, W. J. (2011). Hybrid offerings: how manufacturing firms combine goods and services successfully. Journal of Marketing, 75, 5-23.

Van Raaij, E. M., \& Stoelhorst, J. W. (2008). The implementation of a market orientation: a review and integration of the contributions to date. European Journal of Marketing, 42, 1265-1293.

Vandermerwe, S., \& Rada, J. (1988). Servitization of business: adding value by adding services. European Management Journal, 6, 314-324.

Vargo, S. L. (2008). Customer integration and value creation: paradigmatic traps and perspectives. Journal of Service Research, 11, 211-215.

Vargo, S. L., \& Lusch, R. F. (2006). Service-dominant logic: what it is, what it is not, what it might be. In R. F. Lusch \& S. L. Vargo (Eds.), The Service- Dominant Logic of Marketing: Dialog, Debate, and Direction, pp. 43-56). Armonk, NY: ME Sharpe.

Vargo, S. L., \& Lusch, R. F. (2011). It’s all B2B... and beyond: toward a systems perspective of the market. Industrial Marketing Management, 40, 181-187.

Walker Jr, O. C., \& Ruekert, R. W. (1987). Marketing's role in the implementation of business strategies: a critical review and conceptual framework. Journal of Marketing, 15-33.

Yin, R. K. (2003). Case study research: Design and methods. Thousand Oaks, CA: Sage Publications.

Zook, C. (2004). Beyond the Core: Expand Your Market Without Abandoning Your Roots, Boston: Harvard Business School Press 


\section{Acknowledgements}

The authors are indebted to three anonymous reviewers for insightful comments and to Keith Crosier for his patient and invaluable editing services. Finally, the authors gratefully acknowledge the financial support from the Swedish Governmental Agency for Innovation Systems (Vinnova).

\section{Declaration of conflicting interests}

The authors declare that there are no potential conflicts of interest with respect to the research, authorship, or publication of this article. 
Table 1. The case firms: niche, market position, market share, and main customers

\begin{tabular}{|c|l|l|l|l|}
\hline Firm & Core niche & $\begin{array}{l}\text { Market } \\
\text { position }\end{array}$ & Market share & Main customers \\
\hline A & Metal powder & Market leader & $\begin{array}{l}\text { 30-40\% of total } \\
\text { niche market }\end{array}$ & $\begin{array}{l}\text { Automotive } \\
\text { industry }\end{array}$ \\
\hline B & High-quality & Market leader & $\begin{array}{l}\text { 30-40\% of total } \\
\text { niche market }\end{array}$ & $\begin{array}{l}\text { Automotive } \\
\text { industry }\end{array}$ \\
\hline $\boldsymbol{C}$ & High-quality & Market leader & $\begin{array}{l}\text { 30-40\% of total } \\
\text { niche market }\end{array}$ & $\begin{array}{l}\text { Automotive } \\
\text { industry; } \\
\text { electronics industry }\end{array}$ \\
\hline
\end{tabular}




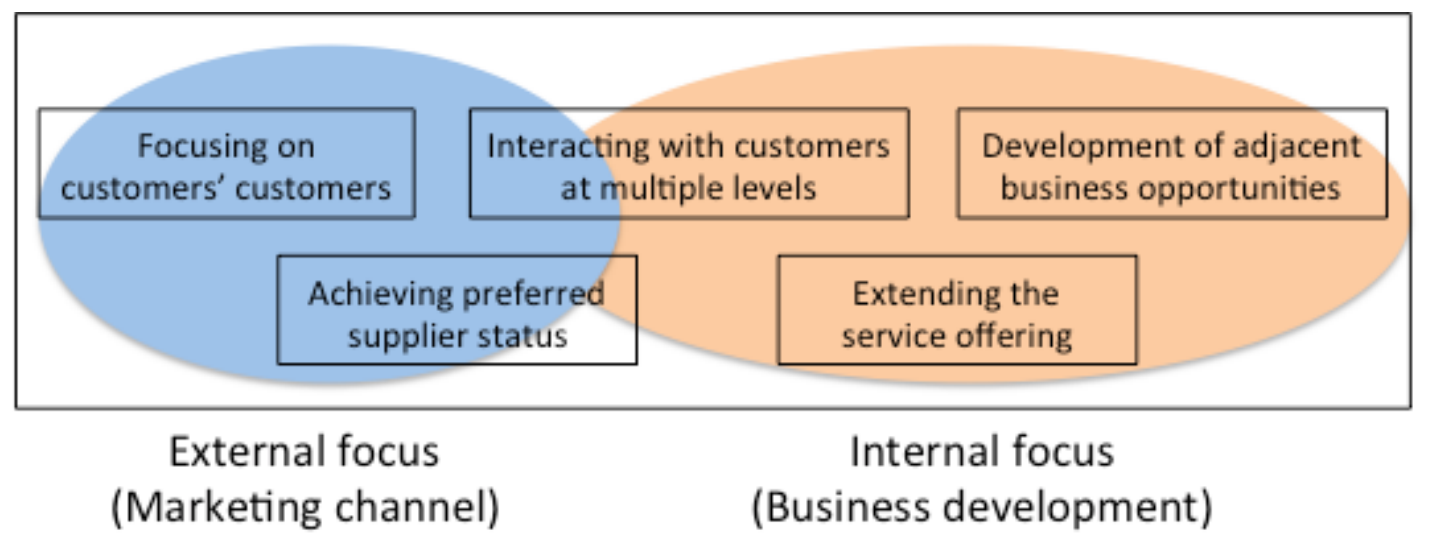

Figure 1. Five key activities underpinning a proactive niche market strategy 
Table 2. Managerial implications of the key activities

\begin{tabular}{|c|c|c|c|}
\hline Activity & Managerial goals & $\begin{array}{c}\text { Potential managerial } \\
\text { implications }\end{array}$ & $\begin{array}{l}\text { Key managerial } \\
\text { actions }\end{array}$ \\
\hline $\begin{array}{l}\text { Focusing on } \\
\text { customers' customers }\end{array}$ & $\begin{array}{l}\text { Transform the } \\
\text { marketing channel by } \\
\text { influencing customers' } \\
\text { customers. }\end{array}$ & $\begin{array}{l}\text { Deeper knowledge of } \\
\text { customer needs and } \\
\text { businesses. } \\
\text { Improved processes and } \\
\text { applications at both the } \\
\text { customer and industry } \\
\text { levels. } \\
\text { Ability to develop } \\
\text { attractive and } \\
\text { customized offerings. }\end{array}$ & $\begin{array}{l}\text { Create arenas for } \\
\text { interacting with } \\
\text { downstream actors. } \\
\text { Establish proactive } \\
\text { sales roles focusing } \\
\text { on the entire } \\
\text { marketing channel. }\end{array}$ \\
\hline $\begin{array}{l}\text { Achieving preferred } \\
\text { supplier status }\end{array}$ & $\begin{array}{l}\text { Work with all } \\
\text { members of the } \\
\text { marketing channel and } \\
\text { influence downstream } \\
\text { actors' development } \\
\text { processes. }\end{array}$ & $\begin{array}{l}\text { Stronger brand equity } \\
\text { throughout the } \\
\text { marketing channel. } \\
\text { Stronger position in } \\
\text { marketing channel. }\end{array}$ & $\begin{array}{l}\text { Encourage brand- } \\
\text { building activities } \\
\text { and reinforce a very } \\
\text { high reputation. }\end{array}$ \\
\hline $\begin{array}{l}\text { Interacting with } \\
\text { customers at multiple } \\
\text { levels }\end{array}$ & $\begin{array}{l}\text { Ensure that customer } \\
\text { interaction takes place } \\
\text { at several levels. }\end{array}$ & $\begin{array}{l}\text { Activities become } \\
\text { customer-driven. } \\
\text { Access to deep customer } \\
\text { knowledge and } \\
\text { application-specific } \\
\text { knowledge throughout } \\
\text { the firm. } \\
\text { Opportunity to build } \\
\text { customer relationships at } \\
\text { several organizational } \\
\text { levels. }\end{array}$ & $\begin{array}{l}\text { Encourage and } \\
\text { create processes for } \\
\text { customer interaction } \\
\text { at several levels and } \\
\text { in several functions. }\end{array}$ \\
\hline $\begin{array}{l}\text { Extending the service } \\
\text { offering }\end{array}$ & $\begin{array}{l}\text { Map existing services } \\
\text { and extend the offering } \\
\text { with both free and } \\
\text { paid-for services. }\end{array}$ & $\begin{array}{l}\text { Increase profit margins } \\
\text { with high-value service } \\
\text { elements. } \\
\text { Enable premium pricing } \\
\text { through high-value } \\
\text { offerings. } \\
\text { Improve customer } \\
\text { engagement and lock out } \\
\text { competitors. }\end{array}$ & $\begin{array}{l}\text { Formalize (in a } \\
\text { portfolio) service } \\
\text { offerings (both } \\
\text { existing and future) } \\
\text { and clarify links to } \\
\text { the product } \\
\text { offerings. } \\
\text { Decide what services } \\
\text { to charge for. }\end{array}$ \\
\hline $\begin{array}{l}\text { Securing future } \\
\text { growth through } \\
\text { “adjacent” business } \\
\text { opportunities }\end{array}$ & $\begin{array}{l}\text { Ensure that existing } \\
\text { knowledge and } \\
\text { products are exploited } \\
\text { in “adjacent” market } \\
\text { areas. }\end{array}$ & $\begin{array}{l}\text { Ability to develop new } \\
\text { offerings and facilitate } \\
\text { customers' business } \\
\text { development. } \\
\text { Increase turnover } \\
\text { through market } \\
\text { development (new } \\
\text { markets). }\end{array}$ & $\begin{array}{l}\text { Encourage } \\
\text { opportunities to } \\
\text { create new ideas. } \\
\text { Facilitate business } \\
\text { development } \\
\text { together with lead } \\
\text { customers. }\end{array}$ \\
\hline
\end{tabular}




\section{Appendix A: An overview of the data collection process.}

\begin{tabular}{|c|c|c|c|}
\hline Stage in process & Description & Actors & Background/Foundation \\
\hline $\begin{array}{l}\text { 1. First interview } \\
\text { round with all nine } \\
\text { firms }\end{array}$ & $\begin{array}{l}\text { General interviews aiming to capture } \\
\text { challenges and opportunities on several } \\
\text { levels for firm in the steel industry. } \\
\text { This was very early in the overall } \\
\text { research project and served to guide the } \\
\text { future sub-research projects. }\end{array}$ & All nine firms & $\begin{array}{l}\text { A first general interview guide } \\
\text { geared to capture challenges } \\
\text { and opportunities within the } \\
\text { industry }\end{array}$ \\
\hline $\begin{array}{l}\text { 2. Focus group with } \\
\text { all nine firms }\end{array}$ & $\begin{array}{l}\text { This served as an arena to discuss and } \\
\text { to validate that our found } \\
\text { challenges/opportunities indeed were } \\
\text { of interest to all firms. }\end{array}$ & All nine firms & $\begin{array}{l}\text { A general focus group, based on } \\
\text { findings from the first interview } \\
\text { round, to validate and } \\
\text { concretize challenges and } \\
\text { opportunities }\end{array}$ \\
\hline $\begin{array}{l}\text { 3. Second interview } \\
\text { round with the three } \\
\text { selected case firms }\end{array}$ & $\begin{array}{l}\text { These interviews were aimed at senior } \\
\text { market managers, chief executives and } \\
\text { managers responsible for certain niche } \\
\text { categories in the three case firms. The } \\
\text { aim was to capture the broader } \\
\text { strategic picture. }\end{array}$ & $\begin{array}{l}\text { The selected } \\
\text { three case } \\
\text { firms }\end{array}$ & $\begin{array}{l}\text { A second interview guide was } \\
\text { developed based on the } \\
\text { literature of B2B marketing, } \\
\text { service marketing and niche } \\
\text { market strategy }\end{array}$ \\
\hline $\begin{array}{l}\text { 4. Focus group with } \\
\text { all nine firms }\end{array}$ & $\begin{array}{l}\text { This focus group served primarily as a } \\
\text { validation exercise and gave the } \\
\text { researchers an opportunity to test ideas } \\
\text { and preliminary analyses. }\end{array}$ & All nine firms & $\begin{array}{l}\text { This focus group discussion } \\
\text { was based on findings } \\
\text { (preliminary analyses and } \\
\text { tentative findings) from the } \\
\text { interviews from the second } \\
\text { round. }\end{array}$ \\
\hline $\begin{array}{l}\text { 5. Third interview } \\
\text { round with the three } \\
\text { selected case firms }\end{array}$ & $\begin{array}{l}\text { These interviews were aimed at a } \\
\text { broader range of respondents in order } \\
\text { to capture, in more detail, how these } \\
\text { firms went about their market } \\
\text { activities. Respondents came from a } \\
\text { variety of functions within the firm: } \\
\text { chief executives, finance directors, } \\
\text { production directors, R\&D managers, }\end{array}$ & $\begin{array}{l}\text { The selected } \\
\text { three case } \\
\text { firms }\end{array}$ & $\begin{array}{l}\text { The third round of interviews } \\
\text { was based on a refined and } \\
\text { developed version of the } \\
\text { previous interview guide. This } \\
\text { was used to further penetrate } \\
\text { the issue of niche market } \\
\text { strategies and to get a more } \\
\text { complete as well as broader }\end{array}$ \\
\hline
\end{tabular}




\section{IMM Manuscript 14-515}

\begin{tabular}{|l|l|l|l|}
\hline & $\begin{array}{l}\text { business sector managers, senior } \\
\text { market managers, technical sales } \\
\text { managers and those with responsibility } \\
\text { for quality control. }\end{array}$ & $\begin{array}{l}\text { empirical base (among other } \\
\text { things for triangulation } \\
\text { purposes). }\end{array}$ \\
\hline $\begin{array}{l}\text { 6. Focus group with } \\
\text { all nine firms }\end{array}$ & $\begin{array}{l}\text { The aim of this focus group was to } \\
\text { validate findings but also to gauge the } \\
\text { validity of our findings to the larger } \\
\text { group of nine firms. }\end{array}$ & All nine firms & $\begin{array}{l}\text { This focus group was based on } \\
\text { findings from the interviews } \\
\text { and structured, as the paper, } \\
\text { around the five found activities } \\
\text { and the concept of a proactive } \\
\text { niche market strategy. }\end{array}$ \\
\hline
\end{tabular}




\section{Appendix B: General interview guides}

First interview round - Interviews with respondents from all nine firms

Introduction

Role and position in the company?

\section{Challenges}

What are the challenges for the company/industry/market and for yourself in your position?

\section{Customers}

Who are your customers (present and potential)?

How do you think your customers view you?

What do your customers demand/need/want?

\section{Production}

Tell us about your production?

To what degree is your production flexible?

Market channel and industry structure

How would you characterize your competition and your industry?

What does your value chain/market channel look like?

\section{Offers}

What do you sell today?

What does your offers look like?

How do you perceive future offers?

\section{Opportunities}

What are the future opportunities? For the industry, firm, offers, and regarding technology development?

How do you determine success in your company? 
Second interview round - Interviews with respondents in the three case firms

\section{Introduction}

Role and position in the company?

\section{Challenges}

What challenges do you see for your company today? (Market and internally)

What are your strategic aims in the long term?

\section{Market strategies}

What firms do you see as your main competitors? Why?

What is your main market and customers?

How do you see your market and your market position?

What are you competitive advantages?

Would you define your company as a niche player?

What makes you a niche player?

\section{Offers}

What are your market offers?

How do you differentiate (and/or customize) your offers to customers?

How do you see the range of goods and services (portfolio) that you offer on the market?

What do customers demand/need/want? Are there any customer demands you cannot deliver today, that you want to develop?

What does your selling process look like? Who is involved?

\section{Customers and relationships}

Who are your customers?

What type of relationship do you have with your customers?

How do you interact? 
What is customer value?

\section{Services and branding}

What kind of services do you offer?

What is the role of different types of services?

What role does brands play for your company, customers and in the industry?

\section{Channel and industry structure}

What is the structure of your market channel?

Who has power in the channel? Why?

How do you approach the channel?

\section{Into the future}

What do you think are the most important factors for you to succeed in the future?

What are the major challenges ahead in terms of competing in the market?

How do you determine success in your company? 


\section{Third interview round - Interviews with respondents in the three case}

\section{Introduction}

Role and position in the company?

\section{Challenges}

What challenges do you see for your company today? (Market and internally)

What are your strategic aims in the long term?

What firms do you see as your main competitors? Why?

What is your main market and customers? How do you see your market and your market position?

\section{Market niche strategy}

Would you define your company as a niche player? Why? Regarding market or product?

What makes you a niche player? Why?

What possible benefits does this admit?

How do you work to develop your market niche and your customer base?

How do you work with existing customers?

How do you see your market niche?

\section{Offers}

What are your market offers?

How do you differentiate your offer to customers?

How do you see the range of goods and services (portfolio) that you offer on the market? Are you missing something?

What do customers demand (products, services, value)? Are there any customer demands you cannot deliver today, that you want to develop?

How do you work to create value in the market? Downstream (the customer's customer)? What does your selling process look like? Who is involved? 
How is the offer delivered to the customer?

How do you develop offers (incl product development)?

\section{Services and brand}

What kind of services do you offer? To whom?

What is the role of different types of services?

What role does brands play for your company, customers, and in the industry?

\section{Customers and relationships}

Who are your customers?

What type of relationship do you have with your customers?

How do you interact?

What is customer value?

\section{Market channel}

What is the structure of your market channel?

Who has power in the channel? Why?

How do you approach the channel?

\section{Into the future}

What do you think are the most important factors for you to succeed in the future?

What are the major challenges ahead in terms of competing in the market?

How do you determine success in your company? 